palaeocurrents directed to the north and south-west (fig. $5 \mathrm{~A}$ ). A rich fish fauna was collected from a mudstone unit in this member. To the west, towards the Stauning Alper fault, the arkoses of the Arkosedal and Ødemarksdal Members occur. The arkoses of the Arkosedal Member interfinger with the sediments of the Snekuppel Member and have palaeocurrents directed to the east (fig. 5 B). Further west, against the Stauning Alper fault, the Konglomeratpas Member is a conglomerate lithology, rather similar to the conglomeratic association of the Rødeø Conglomerate.

The overall environmental picture of the Gureholmsdal Formation is similar to that of the Rødeø Conglomerate. An active fault line on the west of the basin was generating coarse clastic sediments which were carried out into the basin either on alluvial fans or by flash floods. In the east of the basin, an independent sediment dispersion system was distributing micaceous sands, probably in a broad, fluviatile flood plain.

\title{
References
}

Bütler, H. 1957: Beobachtungen an der Hauptbruchzone der Küste von Zentral-Ostgrönland. Meddr Grenland 160, 1.79 pp.

Bütler, H. 1961: Continental Carboniferous and Lower Permian in central East Greenland. In Raasch, G. O. (edit.) Geology of the Arctic 1, 205-213. Toronto Univ. Press.

Kempter, E. 1961 : Die jungpaläozoischen Sedimente von Süd Scoresby Land (Ostgrönland, $71 \frac{1}{2}^{\circ}$ N) mit besonderer Berücksichtigung der kontinentalen Sedimente. Meddr Grønland 164, 1. 123 pp.

\section{PRELIMINARY ACCOUNT OF THE MAPPING OF THE MESOZOIC FORMATIONS OF SOUTH-EAST JAMESON LAND}

\author{
F. Surlyk, R. G. Bromley, U. Asgaard and K. Raunsgaard Pedersen
}

\section{Introduction}

In the 1970 field season, the programme of mapping Jameson Land (Birkelund \& Perch-Nielsen, 1969; Bromley et al., 1970) was continued with a study of the Hurry Fjord region and the area between Mønselv and Raukelv on the south coast (fig. 6).

The geology of the west coast of Hurry Fjord has been studied previously by Hartz (1896), Harris (1926, 1937), Rosenkrantz (1934) and Aldinger (1935), and certain parts of the succession are known in detail. During the 1970 field season, however, special study was made of the phytopalaeontology of the Kap Stewart Formation 


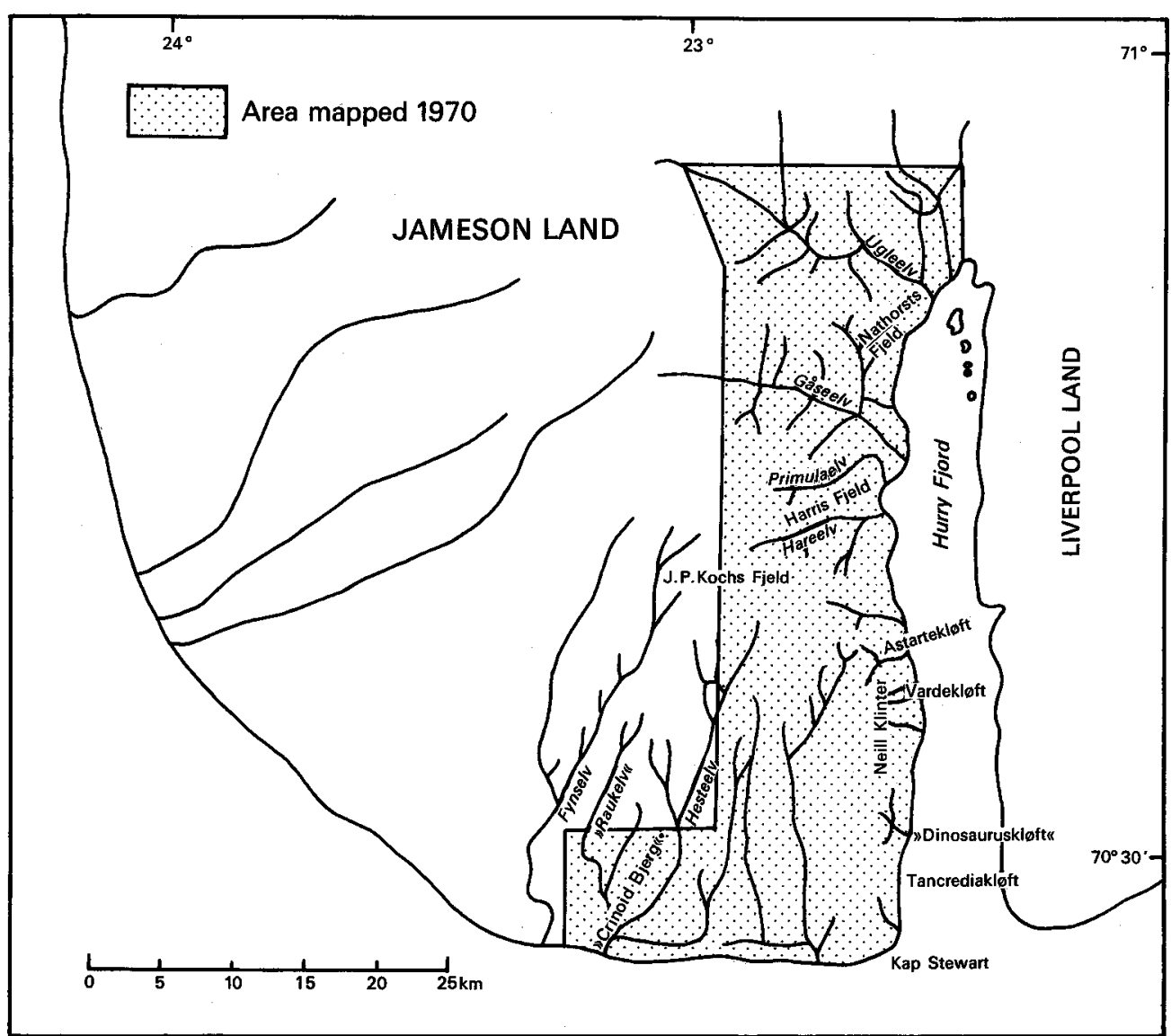

Fig. 6. Index map to show the extent of the area mapped and the localities mentioned in the text.

(K.R.P.), the ichnology of the Neill Klinter Formation (R.G.B. \& U.A.) and the stratigraphy of the Kap Biot Formation and the beds overlying the Neill Klinter Formation (F.S.). These special studies will be published later. A full report of the mapping must wait until a more detailed topographic map is available for the publication of the geological map.

\section{Kap Biot Formation}

Coarse arkosic conglomerates of white, red and light green colour represent the oldest sediments along the west coast of Hurry Fjord. These sediments were included in the Klitdal Formation by Rosenkrantz (1929); here they are correlated with the upper beds of the Kap Biot Formation, the Ørsted Dal Member (Grasmück \& Trümpy, 1969), better known from the northern part of Jameson Land. 
No exposure of the contact with the overlying Kap Stewart Formation was found. In the northern part of the area, at Nathorst Fjeld, the beds are exposed from 100 to $130 \mathrm{~m}$ above sea-level. Further south at Harris Fjeld the exposure is found at sealevel and at Dinosauruskløft the beds have disappeared below sea-level.

The Ørsted Dal Member starts with cross-bedded, coarse, arkosic sandstones and conglomerates. Individual cross-bedded layers vary between 0.3 and $1 \mathrm{~m}$ in thickness. The conglomerates show a mixed pebble assemblage of granites, gneisses, shales and quartzites. The main sediment type is a rather loose gravel consisting of $c .1 \mathrm{~cm}$ pebbles of quartz and feldspar of light greenish and pink colours, often much weathered. Very hard, irregular concretions of dark green or purple colour are common and distinguish the sediment from the overlying Kap Stewart Formation. The gentle slopes of talus between the exposures of the Ørsted Dal beds and the Kap Stewart beds seem to cover red-beds of shaly siltstones with numerous concretions of the above-mentioned type.

\section{Kap Stewart Formation}

(K.R.P.)

The Kap Stewart Formation occurs along the whole west coast of Hurry Fjord. It consists mainly of yellow, grey and greenish current-bedded, arkosic sandstones with conglomeratic layers. Especially in the middle part, dark carbonaceous siltstone and shale layers of variable thickness occur, locally rich in plant fossils. Thin coal seams and root-beds are also developed in this part of the formation.

The thickness of the whole formation was estimated in Nathorst Fjeld and Primulaelv as about $170 \mathrm{~m}$. The altitude of the top of the formation is $390 \mathrm{~m}$ at Nathorst Fjeld, $290 \mathrm{~m}$ at Primulaelv, $250 \mathrm{~m}$ at Astartekløft and $140 \mathrm{~m}$ at Kap Stewart.

The Kap Stewart Formation forms the lowest and least steep portion of Neill $\mathrm{K}$ linter and is consequently mainly hidden by scree. Extensive exposures occur only in some of the larger ravines. These exposures are normally on the north-facing sides of the ravines, which have a steeper gradient than the south-facing sides. Stabilisation by permafrost may explain this difference in gradients.

Large numbers of spore-pollen samples were collected at many horizons throughout the formation, where possible in close connection with the macro-fossils. Sporepollen samples were also collected from the Neill Klinter and Vardekløft Formations.

Detailed investigation of the upper boundary of the formation revealed the presence of a rich plant-bearing horizon in shales directly beneath the overlying Neill Klinter Formation sandstone between Moskusoksekløft and Hareelv.

Macro-fossils, including Lepidopteris ottonis, were collected from the lower part of the Kap Stewart Formation, previously considered to be unfossiliferous (the "barren sandstone" of Harris, 1937). Isolated, well-preserved pieces of wood were also found in these beds. 


\section{Table 1}

\begin{tabular}{|c|c|c|c|c|c|c|}
\hline \multicolumn{3}{|c|}{ Systems, series and stages } & \multicolumn{2}{|c|}{ Lithostratigraphical divisions } & \multirow{2}{*}{$\begin{array}{c}\begin{array}{c}\text { Approximate } \\
\text { thickness in } \mathrm{m}\end{array} \\
>200 \\
5-20 \\
>140\end{array}$} & \multirow{2}{*}{$\begin{array}{l}\text { Depositional environment } \\
\text { Marine - deltaic } \\
\text { Near-shore marine } \\
\text { Off-shore marine }\end{array}$} \\
\hline 竞 & & $\begin{array}{l}\text { L. Valanginian } \\
\text { Berriasian }\end{array}$ & Raukelv Formation & $\begin{array}{l}\text { Fynselv Member } \\
\text { Hesteelv Member } \\
\text { Crinoid Bjerg Member }\end{array}$ & & \\
\hline \multirow{6}{*}{ 品 } & \multirow[t]{2}{*}{ 莒 } & $\begin{array}{l}\text { Kimmeridgian } \\
\text { U. Oxfordian }\end{array}$ & \multicolumn{2}{|c|}{$\begin{array}{l}\text { Hareelv Formation } \\
\text { (= Koch Fjeld Formation } s . l \text { ) }\end{array}$} & 200 & Deltaic, with marine horizons \\
\hline & & & & Hiatus & & \\
\hline & \multirow[t]{2}{*}{$\frac{\mathscr{g}}{\bar{g}}$} & $\begin{array}{l}\text { M. Callovian } \\
\text { U. Bajocian? }\end{array}$ & Vardekløft Formation & $\begin{array}{l}\text { Upper Vardekløft Member } \\
\text { "The Yellow Series" } \\
\text { Lower Vardekløft Member }\end{array}$ & $\begin{array}{c}120-150 \\
30-40 \\
50-70\end{array}$ & $\begin{array}{l}\text { Off-shore marine } \\
\text { Deltaic } \\
\text { Off-shore marine }\end{array}$ \\
\hline & & & & Hiatus & & \\
\hline & \multirow[t]{2}{*}{ 㟥 } & $\begin{array}{l}\text { Toarcian } \\
\text { Pliensbachian }\end{array}$ & Neill Klinter Formation & $\begin{array}{l}\text { Fossiliferous sandstone } \\
\text { Shales/sandstones } \\
\text { Pectinid sandstone }\end{array}$ & 220 & Near-shore marine \\
\hline & & & . & Hiatus & & \\
\hline \multirow{2}{*}{$\begin{array}{l}\text { 量 } \\
\text { 畺 } \\
\end{array}$} & \multirow{2}{*}{ 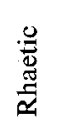 } & & Kap Stewart Formation & & 170 & Fluviatile and lagoonal \\
\hline & & & Kap Biot Formation & Ørsted Dal Member & $>120$ & Fluviatile \\
\hline
\end{tabular}


Harris (1937) divided the Kap Stewart Formation into a lower, unfossiliferous part ("barren sandstone") with a thickness of $85 \mathrm{~m}$ and an upper, "plant-bearing series" of $90 \mathrm{~m}$. In the Fleming Fjord area Grasmück \& Trümpy (1969, p. 55 \& 58) placed the lower boundary of the Kap Stewart Formation at a "widespread bonebed horizon", above the dolomitic upper part of the Ørsted Dal Member of the Kap Biot Formation. They further stated that the cross-bedded sandstones of the lower, barren subdivision of the Kap Stewart Formation (sensu Harris) corresponds to their Ørsted Dal Member with dolomitic horizons.

On the basis of the discovery of Lepidopteris ottonis and other plant macro-fossils in the lower sandstones, the lack of marked lithological boundaries between the "barren sandstone", and the "plant-bearing series",(sensu Harris), and the fact that the "bonebed" of Grasmück \& Trümpy is not present in the sections along Hurry Fjord, there is no justification in excluding the "barren sandstone", from the Kap Stewart Formation in this region.

The boundaries of the Kap Stewart Formation should therefore be retained as defined by Rosenkrantz (1929) and Harris (1937), while the internal subdivision into "barren sandstone", and "plant-bearing series", must be abandoned.

\section{Neill Klinter Formation}

The term Neill Klinter is used here in agreement with the main literature on the subject (Callomon, 1959, 1961 \& 1970; Donovan, 1957). The formation maintains its thickness of $c .220 \mathrm{~m}$ more or less constantly over the distance from Ugleelv to Dinosauruskløft.

At the base, the highly fossiliferous pectinid sandstone of Pliensbachian age can be followed throughout the region. In Gåseelv it is $4.6 \mathrm{~m}$ thick, but thins somewhat and becomes less uniformly cemented in the south. Additional, but poorly fossiliferous, sandstones are intercalated in the basal shales overlying the pectinid sandstone south from Astartekløft (Rosenkrantz, 1934). The sediment, fauna and ichnology of the pectinid sandstone all indicate a rather turbulent and shallow marine environment of deposition.

The overlying sediments begin with interbedded thin sandstones and shales. At some $10 \mathrm{~m}$ above the base, however, the sandstone beds begin to thicken and the shales to diminish, so that the succession is dominated by sandstones with, at some levels, shaly partings. This lithotope provides good preservation of trace fossils at many horizons.

The alternation of argillaceous and arenaceous sediments reflects an alternation of quiet and more turbulent sedimentary conditions. Some of the sandstones are conglomeratic and most are current-bedded. This variation in conditions is also reflected in the trace fossils, which comprise a mixture of Skolithos and Cruziana ichnofacies. The Skolithos association is usually present in the thicker sandstones, 
and is represented by long vertical shafts of Skolithos, shorter, funnel-mouthed Monocraterion and vertical U-tubes. The thinner-bedded sandstone-shale succession, and many of the thicker sandstones, contain trace fossils of the Cruziana association, represented by back-fill structures of sediment eaters. These include Gyrochorte, Muensteria, Scolicia, Phycosiphon, Cochlichnus and finely annulated horizontal tunnels together with many resting traces. No body fossils occur in this series, but the environment of deposition was most probably marine.

The top 50-60 m of the formation is composed almost entirely of sandstone, with body fossils, particularly oysters, preserved at several horizons and indicating a Toarcian age. Trace fossils of the Cruziana association are also preserved, with the introduction of Rhizocorallium, Curvolithus, Ophiomorpha and Thalassinoides.

In both the Pliensbachian and Toarcian sandstones, bivalve shells, particularly oysters, contain abundant borings of acrothoracican cirripedes, bryozoans, probable bryozoans and, less commonly, vermiform animals.

The proportion of feldspar grains in the coarse-grained sandstones generally diminishes upwards, although they are still present in small quantities in the highest sandstones. Glauconite grains also occur in some of the fossiliferous horizons in the higher sandstones.

\section{Vardekløft Formation}

The Vardekløft Formation diminishes considerably southwards, from a thickness of c. $270 \mathrm{~m}$ in Ugleelv to $c .100 \mathrm{~m}$ near Tancrediakløft.

The formation can be mapped as three members. The Lower Vardekløft Member seems to retain a thickness of $c .70 \mathrm{~m}$ over the whole of southern Jameson Land.

The middle member, called "The Yellow Series", is the most conspicuous part of the formation in the northern part of Jameson Land. It attains a thickness of more than $c .500 \mathrm{~m}$ in central Jameson Land. The member decreases considerably in thickness southwards and is only slightly coarser and has a more yellow colour in the weathered condition than the grey shaly siltstones of the lower and upper members. In the southern part of Jameson Land "The Yellow Series", has almost disappeared. At the type locality, i.e. in the Vardekløft area, the thickness is $c .40 \mathrm{~m}$, but the upper limit is never distinctly developed and is best seen as a small terrace or slight change of slope in the profile. North of Vardekløft "The Yellow Series", thickens until, in the inner part of the Ugleelv valley, the member is exposed as the thick, massive, yellow sandstones characteristic of "The Yellow Series", in the northern part of Jameson Land.

The Upper Vardekløft Member consists of light grey shaly siltstones with ellipsoidal concretionary bodies with a length of 1-3 m, smaller calcareous concretions and a few thin sandstone layers.

In the Vardekløft area the uppermost $20 \mathrm{~m}$ of the formation can be distinguished 
as a separate unit. The sediment is shaly siltstone like the rest of the member, but the concretions are extremely hard, light grey and often irregular in shape. They normally contain a core of silicified wood.

Ammonites were collected at two horizons in this uppermost unit. In concretions $15 \mathrm{~m}$ below the top of the Vardekløft Formation several specimens of a Pseudocadoceras sp. were found and in concretions $3 \mathrm{~m}$ below the top of the formation a Kosmoceras from the Erymnoceras coronatum Zone and several Longaeviceras cf. longaevum were found. From the same horizon in the Gåseelv area two specimens of Kosmoceras (Gulielmiceras) cf. gulielmi were collected. These ammonites, together with Middle Callovian ammonites found on Parnas, northern Jameson Land by $T$. Birkelund and J. H. Callomon in 1970, are the first Middle Callovian fossils found in Greenland.

\section{Hareelv Formation}

The Vardekløft Formation is followed by a succession of massive sandstones interfingering with black shale, which Donovan (1957) assigned to the Koch Fjeld Formation. Later authors (Callomon, 1959, 1961, 1970; Birkelund \& Perch-Nielsen, 1969; Birkelund et. al., 1971) all used the name Koch Fjeld Formation for sediments overlying the Vardekløft Formation. This is, however, not in accordance with the original definition of this formation (Rosenkrantz, 1929) and a revision of the names of the youngest formations in the Jameson Land Mesozoic is to be published elsewhere (Surlyk, in press). In this revision two new formations are designated as formal units, viz. the Hareelv Formation and the Raukelv Formation.

The Hareelv Formation comprises the sequence of alternating lenses of sandstones and shales overlying the Vardekløft Formation in southern Jameson Land. The formation begins with a few metres of black shale with hard, rusty concretions. The shale is overlain by c. $200 \mathrm{~m}$ of alternating massive sandstones and black or grey shales. The lateral variation is very pronounced as the sandstones form lenses $c$. $10-20 \mathrm{~m}$ thick and a few hundred metres long. Bedding is only rarely found in the sandstones. About $40 \mathrm{~m}$ above the base of the formation in a more prominent shale horizon, numerous specimens of Upper Oxfordian Amoeboceras spp. were found at many localities. In Hareelv a few specimens of Decipia sp. were collected by J. BruunPetersen in 1970 at approximately the same level.

\section{Raukelv Formation}

One of the authors (F.S.) and J. Bruun-Petersen mapped part of southernmost Jameson Land where sediments of Berriasian age had been found and described by Aldinger (1935). Aldinger's results were confirmed and many ammonites collected. Exposed contacts with the Hareelv Formation were not found, but the thickness 
of the Berriasian could be estimated as $c .400 \mathrm{~m}$. The Raukelv Formation (Surlyk, in press) is designated as comprising the Lower Cretaceous sediments exposed in southern Jameson Land. The formation comprises 3 members from bottom to top:

\section{Crinoid Bjerg Member}

Shaly siltstones with giant concretionary bodies and small calcareous concretions comprising c. $140 \mathrm{~m}$.

\section{Hesteelv Member}

A 5-20 m thick conglomeratic shell-bed (Muschelbank of Aldinger, 1935) almost totally composed of shells of very large bivalves. The Hesteelv Member was found at many localities and constitutes a good marker horizon.

\section{Fynselv Member}

The Hesteelv Member is overlain by massive cross-bedded sandstones with a few shaly or concretionary horizons. The member forms an extensive plateau with deep canyons covering the south-central part of Jameson Land in the Fynselv region.

The $100 \mathrm{~m}$ of shales and sandstones comprising the top of J. P. Koch Fjeld is the type locality of the Koch Fjeld Formation (Rosenkrantz, 1929). On this summit several specimens of Polyptychites sp. were found, indicating probable Valanginian (Lower Cretaceous) age. $200 \mathrm{~m}$ below the summit the Berriasian Hesteelv Member was found. Thus the Koch Fjeld Formation sensu stricto comprises the sediments belonging to the upper part of the Cretaceous beds exposed in the southernmost part of Jameson Land and not, as assumed by Donovan (1957), sediments of Upper Jurassic age overlying the Vardekløft Formation. As the name Koch Fjeld Formation has never been used in accordance with the original definition, it would seem best to abandon it (Surlyk, in press).

\section{References}

Aldinger, H. 1935: Geologische Beobachtungen im Oberen Jura des Scoresbysundes (Ostgrönland). Meddr Grenland 99, 1, $128 \mathrm{pp}$.

Birkelund, T., Håkansson, E. \& Surlyk, F. 1971: New finds of Bathonian, Callovian, and Oxfordian ammonites in northern Jameson Land, East Greenland. Bull. geol. Soc. Denmark 20, 240-259.

Birkelund, T. \& Perch-Nielsen, K. 1969: Field observations in Upper Palaeozoic and Mesozoic sediments of Scoresby Land and Jameson Land. Rapp. Gronlands geol. Unders. 21, 21-35.

Bromley, R. G., Bruun-Petersen, J. \& Perch-Nielsen, K. 1970: Preliminary results of mapping in the Palaeozoic and Mesozoic sediments of Scoresby Land and Jameson Land. Rapp. Grønlands geol. Unders. 30, 17-30.

Callomon, J. H. 1959: The ammonite zones of the Middle Jurassic beds of East Greenland. Geol. Mag. 96, 505-513.

Callomon, J. H. 1961 : The Jurassic System in East Greenland. In Raasch, G. O. (edit.) Geology of the Arctic 1, 258-268. Toronto Univ. Press. 
Callomon, J. H. 1970: Geological map of Carlsberg Fjord - Fossilbjerget area. Meddr Grønland 168, $4,10 \mathrm{pp}$.

Donovan, D. T. 1957: The Jurassic and Cretaceous Systems in East Greenland. Meddr Grønland 155, $4,225 \mathrm{pp}$.

Grasmück, K. \& Trümpy, R. 1969: Triassic stratigraphy and general geology of the country around Fleming Fjord. Meddr Gronland 168, 2, I, 5-76.

Harris, T. M. 1926: The Rhaetic flora of Scoresby Sound, East Greenland. Meddr Grønland 68, 43-147. Harris, T. M. 1937: The fossil flora of Scoresby Sound, East Greenland. 5: Stratigraphic relations of the plant beds. Meddr Grenland 112, 2, $114 \mathrm{pp}$.

Hartz, N. 1896: Planteforsteninger fra Cap Stewart i Østgrønland, med en historisk oversigt. Meddr Gronland 19, 217-247.

Rosenkrantz, A. 1929: Preliminary account of the geology of the Scoresby Sound district. In Koch, L., The geology of East Greenland. Meddr Grenland 73, 2, 135-154.

Rosenkrantz, A. 1934: The Lower Jurassic rocks of East Greenland, I. Meddr Grønland 110, 1, 122 pp.

Surlyk, F. (in press): Upper Jurassic and Lower Cretaceous stratigraphy in southern Jameson Land, East Greenland. Bull. geol. Soc. Denmark 21.

\title{
PRELIMINARY RESULTS OF MAPPING THE UPPER JURASSIC AND LOWER CRETACEOUS SEDIMENTS OF MILNE LAND
}

\author{
E. Håkansson, T. Birkelund, C. Heinberg and P. Willumsen
}

\section{Introduction}

The Mesozoic sediments of eastern Milne Land were mapped during the 1970 field season (map 2).

The Upper Jurassic - Lower Cretaceous sequence of this area has been studied previously mainly by Rosenkrantz (1929), Aldinger (1935) and Callomon (1961). The rich faunas from the area have been described by Spath $(1935,1936)$ and Donovan (1964).

Rosenkrantz (1929) established two lithological divisions for the upper part of the sequence (Cape Leslie Formation and Hartz Fjeld Formation), while Aldinger (1935) investigated the whole sequence from the Caledonian crystalline basement at Charcot Bugt to the top of Hartz Fjeld. He divided the sequence into (a) Charcot Bugt Sandstone, (b) shale and marl from the Upper Oxfordian, (c) Pecten Sandstone from the Upper Oxfordian, (d) shale and marl from the Lower and Upper Kimmeridgian, (e) Glauconite Series from the Upper Kimmeridgian - Portlandian and (f) Hartz Fjeld Sandstone, the last of which includes parts of Rosenkrantz's Cape Leslie Formation. Aldinger's publication (1935) also included a geological map of the eastern part of the Mesozoic area. 